\title{
NON-NOMINATIVE SUBJECTS IN COMPARISON
}

\author{
Josef Bayer \\ University of Konstanz \\ Fachbereich Sprachwissenschaft \\ Universität Konstanz \\ Universitätsstr. 10 \\ D-78457 Konstanz \\ Germany \\ Josef.Bayer@uni-konstanz.de
}




\title{
NON-NOMINATIVE SUBJECTS IN COMPARISON
}

\author{
Josef Bayer \\ University of Konstanz
}

\section{Introduction}

Among languages with a sufficiently rich system of morphological Case we observe unmarked constituent orderings which deviate from the "nominative preceding non-nominative" pattern. This deviation, if one wants to call it that way, is to a large extent lexically and semantically predictable. Languages of this kind are classified as languages that permit nonnominative subjects. As is well known, however, they differ quite radically as to certain syntactic consequences which the non-nominative-first pattern may have. German and Icelandic are closely related Germanic languages which - not surprisingly - show strong similarities in their argument structures and syntax of Case. Nevertheless, they differ by the fact that non-nominative prominent DPs in Icelandic behave like genuine subjects while they do not (or do to a lesser extent) in German. The goal of the present article is to explore the possibility of deriving differences in "subjecthood" from the basic order of constituents. Icelandic has a head-initial VP which is separated from an external argument by a functional head $\mathrm{F}^{0}$ (or a number of functional heads), i.e., the order is SpecFP $F^{0}\left[{ }_{v P} V\right.$...]. German has a head-final VP instead. There are strong indications that the or$\operatorname{der}[\mathrm{VP} \ldots \mathrm{V}] \mathrm{F}^{0}$ does not give rise to a functionally defined position SpecFP. Following work by others, I will argue that this is related to the nature of $\mathrm{F}^{0}$. Given that both German and Icelandic (and perhaps all languages) have a prominent argument that has certain syntactic and semantic properties one associates with the notion "subject", my conjecture is that the difference derives from the fact that head-initial languages show a grammaticalization of the prominent argument that is missing in head-final languages. I will try to derive this grammaticalization from the nature of $\mathrm{F}^{0}$ and explore how far this can take us.

Although the German/Icelandic contrasts will set the stage, data from other languages - primarily from Bengali - will be drawn into the argumentation. I will first turn to expletives, then point out the relevant similarities and differences between German and Icelandic. After this 
there will be a section on argument structure and unmarked ordering. The next section will turn to Minimalist assumptions about checking under c-command, the Extended Projection Principle (EPP) and reasons for displacement. We will then explore how in head-final languages checking can take place under m-command. Finally we will indicate how the different mechanisms for checking can yield the observed differences in "subjecthood." I will throughout use the informal term "subject" for convenience. This usage should not imply that there is actually such a thing in the theory of grammar.

\section{Expletives}

Certain languages insist on the presence of a formal pleonastic subject, others do not. In impersonal passives, for instance, Dutch, Icelandic, Swedish and other languages require an expletive element in subject position; (cf. Rosengren (2002) for a recent presentation of the data and relevant discussion). This is not the case in Bengali (Bangla), German, Turkish, and numerous other languages. Languages of the latter group either altogether lack a lexical element that would serve as an expletive, or, if they have one, require its absence in impersonal passives, as is the case in the German embedded clause shown in (5).

(1) Dutch

dat *(er) gedanst wordt

that there danced becomes

'that there is dancing' / 'that somebody danced'

(2) Icelandic

að *(pað) verið dansað

that there becomes danced

(3) Swedish

att *(det) dansas

that there danced.is

(4) Bengali

je nac hocche

thatdance happening-is 
(5) German

dass $\left({ }^{*} e s\right)$ getanzt wird

that it danced becomes

(6) Turkish

Ahmed dans ed -il -diğ -in - $i \quad$ söyle -di

Ahmed dance do PASS FN 3SG ACC say PAST

'Ahmed said that there was danced'

Interestingly, an expletive appears in German as soon as a root clause is chosen. German being a verb second (V2) language in which the finite verb in the root clause moves into the head position of $\mathrm{CP}$, and in which SpecCP is filled by phonetic material, an expletive element appears in SpecCP, if nothing else is moved there.

(7) German
a. Getanzt wird $t$ danced becomes
b. Es wird getanzt
it becomes danced

The same is true of Kashmiri, a typical SOV-language which also shows the V2-property. The Kashmiri data in (8) are taken from Wali and Koul (1997). They show that the element yi appears when the pre-verbal position is not filled by another element.

(8) Kashmiri
a. vuchini a:v $\mathrm{t}$ zi ...
seen come-PASS that
'Seen was that ...'
b. yi a:v vuchini zi ...
it come.PASS seen that
'It was seen that ...'

According to Peter Hook (p.c.) Kashmiri has a limited amount of other elements that serve a similar function as expletives and cannot occur elsewhere in the clause.

The appearance of an expletive seems to be forced by the presence of a verb-related functional head such as $\mathrm{I}^{0}$ and $\mathrm{C}^{0}$. Languages which lack an initial functional head of this kind, do not show expletive subjects. German differs from other Germanic languages such as English, Dutch, 
Scandinavian in not allowing an expletive at the level of IP. This establishes a certain typological link between German and genetically related but rather distant languages such as Bengali and Kashmiri. Icelandic and Swedish are clearly SVO-languages, and Bengali, Kashmiri (as well as genetically unrelated languages such as Turkish) are clearly SOV-languages. The basic typology of Dutch and German seems less perspicuous. Officially they count as SOV, but the expletive facts suggest that Dutch has a pre-VP functional head, while German has either a post-VP functional head which does not activate a specifier or no such head at all. According to Haider (1993), German lacks IP altogether, and C selects only a VP which is enriched with finiteness features, and which includes the subject. Haider's theory presupposes that only initial functional heads are syntactically active, and that there are no final functional heads to begin with. This impression is supported by the distribution of clitic pronouns. In German, clitic pronouns move to $C^{0}$, the so-called "Wackernagel position," while in Dutch they move to a position below the subject which one may identify as a silent $\mathrm{I}^{0}$-position (cf. Jaspers 1989 and Zwart 1991 on Dutch and an overview in Cardinaletti 1998). Under the assumption of the universality of the EPP, German must have an empty expletive. But this would be at odds with the fact that German is not a pro-drop language. Pro-drop would strangely be confined to (certain) expletives in subordinate clauses. My assumption is therefore that the EPP does not hold universally, and that the persistent absence of audible expletives in constructions or entire languages is a serious reason to believe that these constructions/languages do not license an expletive at all. ${ }^{1}$

\section{Unmarked non-nominative first arguments in the clause}

Consider the following illustrative examples from German, Icelandic and Bengali in which the unmarked word order requires a non-nominative NP to occupy the first position. The German data show accusative and dative experiencer arguments with or without nominative theme arguments: ${ }^{2}$

1 For criticism and a relevant alternative to the universal pro/expletive theory cf. Brandner (1993). I do not deny that head-initial pro-drop languages may have empty expletives. As Raposo \& Uriagereka (1990) and Kaiser (2002) show, Galician Spanish, Portuguese and the Spanish of the Domenican Republic allow overt expletives.

2 (9a,c) and similar sentences with only one non-nominative argument can in addition use es ('it'): dass es mich friert; dass es mir schlecht wird. This fact should not lead us to the conclusion that $e s$ is an expletive. In my view it is not, but I cannot present the arguments for reasons of space. 
(9) German
a. dass mich friert
that me-ACC freezes
'that I am cold'
b. dass mich der Streit anödet
that me-ACC the quarrel-NOM bores
'that the quarrel bores me'
c. dass mir schlecht ist
that me-DAT bad is
'that I am sick'
d. dass mir der Streit missfällt
that me-DAT the quarrel-NOM displeases
'that I am fed up with the quarrel'

The following Icelandic data from Sigurðsson(2000) show dative, accusative as well as genitive experiencer arguments which may be followed by theme arguments in the nominative or accusative:

(10) Icelandic
a. Henni var kalt
her-DATwas cold
'she felt cold'
b. Henni leiddust strákanir
her-DATbored boy-the-NOM
'She was bored by the boy'
c. Hana vantði vinnu
her-ACClacked job-ACC
'She didn't have a job'
d. Hennar var saknað
her-GEN was missed
'She was missed'

The Bengali data in (11) and (12) are drawn from Klaiman (1980). Bengali lacks a morphological dative and uses for its "dative" constructions the - $r$ form which stands for possessives and is glossed here with GEN(itive) for purely expository reasons. I also use the Case label ACC without implying that there is an accusative as opposed to a dative. Perhaps Bengali has only one "objective" Case. 
(11) Bengali

a. amar tomake cai

I-GEN you-ACC wants

'I need you (me is need of you)'

b. tar nak dake

(s)he-GEN nose calls

'(S)he snores'

c. tar ošukh koreche/hoyeche

(s)he-GEN illness made / became

'(S)he became unwell'

Many of the "dative" constructions have nominative counterparts, the semantic difference being that the latter express volitionality while the former have a non-volitional interpretation, e.g., ${ }^{3}$

(12) a. ami tomake cai

I-NOM you-ACC want

'I want you'

b. še dhon kore nak dakchilo

(s)he-NOM pretend doing nose called

'(S)he was faking a snore', '(S)he pretended to snore'

\section{Subjecthood in Icelandic}

As has been pointed out by Andrews (1976), Zaenen et.al. (1985) and Sigurðsson(1989), there are a number of constructions which show that the non-nominative first argument in Icelandic passes classical tests for subjecthood. I will not present all of them in detail but will rather confine myself to a list, and then turn to two of them in more detail which I take to be of central relevance for a comparison with Bengali and German (see also the contributions by Sigurðsson and Fischer in this volume).

First, the nominative subject takes the first position after $C$ in an embedded clause. Icelandic, not being a scrambling language, does not allow an object there. Non-nominatives as in María spurð̃i hvort mér hafð̈i leidist Haraldur ('Maria asked whether me $_{\mathrm{DAT}}$ had bored Harald ${ }_{\mathrm{NOM}}$ '), however, are allowed in this position. Second, the raised element in accusativus cum infinitivo constructions and other cases of raising must be the subject

3 (12b) is a slightly corrected example from Klaiman (1980) with which my informants were not entirely happy. 
no matter which Case it bears. Dative subjects undergo raising like nominative subjects whereas non-subject nominatives ("deep objects") fail to undergo raising. Third, for most speakers only subjects can bind reflexives, but as shown by Honum leiðist konan \{sin/?*hans\} ('him ${ }_{\mathrm{DAT}}$ bores wife \{self's/his\}'), non-nominative subjects can bind reflexives too. ${ }^{4}$ Fourth, if the expletive $p a ð$ is inserted in first position, a heavy indefinite subject can be postposed, i.e., pað-insertion affects the external argument. As the grammaticality of pað leiddist petta bara nokkrum málfrcedingum ('it bored this $_{\text {NOM }}$ only several linguists ${ }_{\text {DAT }}$ ') shows, this principle applies also to dative subjects. Fifth, as Sigurðsson points out, the subject can come right after $\mathrm{C}$ or after the negative ekki, but when it is a clitic, it can be only after C, not after ekki. The distribution of the dative clitic 'er in Hefur ('er) ekki (*'er) oft leiðst Haraldur? ('has him ${ }_{\mathrm{DAT}}$ not often bored Harald ${ }_{\mathrm{NOM}}$ ') suggests that this clitic is a subject. There are two further tests which should be looked at in more detail since they contrast Icelandic with German rather perspicuously. These concern cases of control and conjunction reduction.

4 Throughout this article I will refrain from discussing anaphor licensing. The reason is that in cross-linguistic perspective the arguments in favor of dative subjects that stem from anaphor licensing are not fully conclusive. Jayaseelan $(1990 ; 2002)$ provides evidence that the licensing of the Malayalam reflexive taan is neither controlled by c-command nor by a subject antecedent. Jayaseelan (1998) argues that the relevant notion is perspective rather than subject-orientedness. As for the German-Icelandic contrast, although German nonnominative experiencers lack many of the subject properties of their Icelandic correspondents, they do license reciprocals and reflexives with selbst ('self') as shown in (i) and (ii), whereas dative objects do not as shown by (iii):

(i) Den Alkoholikern hat vor einander gegraut / Dem Alkoholiker hat

the alcoholics-DAT has from each-other disgusted/the alcoholic-DAT has

vor sich selbst gegraut

from himself disgusted

(ii) Die Alkoholiker hat vor einander geekelt /Den Alkoholiker hat

the alcoholics-ACC has fromeach-other disgusted/the alcoholic-ACC has

vor sich selbst geekelt

from himself disgusted

(iii) *Ich habe den Gästen einander vorgestellt

I have the guests-DAT each-other introduced

If the dative DP in (i) had to strictly c-command the anaphor, this would be surprising. There is abundant evidence that the dative (and perhaps a quirky accusative too) is dominated by a $\mathrm{K}($ ase) Phrase (KP) in which $\mathrm{K}$ would be a blocking force against c-command. Cf. Bayer, Bader and Meng (2001). 


\subsection{Control}

While it is generally assumed in GB-theory that the subject of infinitives is PRO and as such is Case-less or ungoverned, or - as in the Minimalist Program - that it is PRO and therefore bears the default Case nominative, Icelandic shows that the empty category PRO can also be a representative of non-nominative Case. The verbs in question unambiguously require nonnominative Case on their experiencer arguments; thus, it appears that PRO must also be allowed to correspond to non-nominative Case. $(13 \mathrm{a}, \mathrm{c})$ are from Sigurðsson(1989) and (13b) with a slight change from Zaenen et al. (1985).

(13) a. hann vonast til að PRO leiðast ekki he-NOMhopes for to DAT bores not 'He hopes that he won't be bored'

b. Ég vonast til að PRO vanta ekki peninga I-NOM hope for to ACC lack not money-ACC 'I hope to not lack money'

c. Við vonuðumst til að PRO verðda hjálpað we hoped for to DAT become helped 'We hoped to be helped' / 'We hoped to get help'

The Icelandic data suggest that it is the subject which must be empty in the infinitive and not necessarily the nominative subject. In fact, as shown by (14), a non-subject nominative can stay in an infinitival clause.

(14) Hún vonast til að PRO leiðast ekki bókin she hopes for to DAT bore not book-the-NOM 'She hopes not to find the book boring'

\subsection{Conjunction reduction}

Another remarkable fact about Icelandic is that the subject of the second member of a conjoined clause can be elided, although it is formally distinct from the first sentence's subject. As Zaenen et al. (1985) put it: "It is not the morphological identity that counts, it is the grammatical function." 
(15) a. hann segst vera dugleguren honum finnst he-NOM says-self to-be diligent but he-DAT finds verkefnid of pungt the-homework too hard 'He says he is diligent, but finds the homework too hard'

b. Við vorum svangir og ekkur vantaði peninga we-NOM were hungry and us-DAT lacked money-ACC 'We were hungry and didn't have any money'

It is important to notice that these examples cannot be treated as VPconjunctions because in (15b) vorum (1p) and vantaði (3sg) retain their respective agreement.

\section{Quirky subjects in German and other OV-languages?}

As is well known since Zaenen et al. (1985), German behaves rather differently from Icelandic when the tests for subjecthood in 4. are applied, despite the fact that the two languages are so similar with respect to argument structure and Case linking. Let me confine myself again to control and conjunction reduction as these render the most perspicuous differences. I will also use Bengali data.

\subsection{Control}

As the German examples in (16) show, the quirky experiencer in $(16 a, b)$ or dative in the passive clause in (16c) cannot be nullified. The verb grauen ('dread', 'disgust') requires a dative, the verb interessieren ('interest') requires an accusative experincer argument; helfen ('help') requires a dative object which could be expected to promote to subject in the passive (which in fact it does not).

(16) a. ${ }^{*}$ Er fürchtete PRO vor dem Abend zu grauen he feared DAT from the evening to disgust 'He was afraid of being put off by the evening (party)'

b. *Erhoffte PRO der neue Roman zu interessieren he hoped ACC the new novel-NOM to interest 'He hoped the new novel would interest him' 


\section{c. *Wir hofften PRO geholfen zu werden we hoped DAT helped to become 'We hoped to be helped' / 'We hoped to get help'}

The reason for the ungrammaticality of (16b) might be seen in the presence of an illicit nominative, but there is some evidence that - like Icelandic - German infinitives do not disallow nominatives in principle:

a. Die Gefangenen haben versucht [PRO einer nach dem
the captives have tried one-NOM after the anderen durch den Tunnel zukriechen] other through the tunnel to crawl 'The captives tried to crawl one after the other though the tunnel'

b. Odysseus hat versucht [PRO als ein alter Bettler verkleidet Ulysses has tried as an old beggar-NOM disguised in das Haus zu gelangen] in the house to get 'Ulysses tried to get into the house in the disguise of an old beggar'

As long as there is a PRO argument, the following associated reciprocal part ein-er and the -er in the adjective alt-er unambiguously shows nominative Case.

Experiencer constructions with a nominative theme argument show that, unlike in Icelandic, it is always the nominative theme argument which is nullified under control:
(18)
Der Roman wurde besprochen [ohne PRO jemanden ernsthaft interessiert zuhaben] seriously interested to have the novel was discussed without NOM anyone-ACC 'The novel was discussed without anyone having taken a serious interest in it.'

Obviously, the relative prominence of the experiencer argument in comparison with the theme argument does not suffice to license PRO. It is rather the null Case of the nominative which serves as the only argument that can be licensed as PRO by the infinitive.

According to Jogamaya Bayer (p.c.), the "quirky" genitive subject seems to be unavailable as a PRO subject in Bengali. Consider the simplex nominative-taking verb hãša ('to laugh') versus the complex genitive- 
taking verb hãši paowa ('laugh get'; 'to be struck by a laugh'). As the examples in (19) show, the former takes a nominative subject while the latter requires a genitive subject.
a. ram hẽšeche
ram-NOM laughed
b. ramer hãši peyeche
ram-GEN laugh got

In perfective participial clauses in which a PRO subject is required, the nominative is replaced by PRO, but the genitive cannot be:
a. [PRO hẽše hẽše] ramamake bolchilo je...
NOM laughing laughing ram me told that... 'Constantly laughing, Ram told me that ...'
b. *[PRO hãši peye $] \quad$ ramamake bolchilo je... GEN laugh having-gottenram me told that...

This indicates that in comparison with the nominative, the genitive is not formally identified as a subject and can therefore not be replaced by PRO. ${ }^{5}$ Data of this sort need to be looked at with extra care because there are predicates which allow different Case frames; bhoy paowa ('fear become', 'to be frightened'), bhoy kora ('fear make', 'to be frightened'), icche kora ('wish make', 'to desire') and perhaps others take a dative experiencer subject but alternatively also a nominative subject. These verbs may always appear with a PRO-subject. In this case it is expected that PRO corresponds to nominative and not to genitive Case. Verbs which exclusively take a genitive experiencer subject such as ... lagano ('to touch', 'to strike as ...') never seem to show up in such constructions. There are some predicates with paowa ('get') which require exclusively dative experiencers, e.g., khide

5 Non-finite reason clauses appear to be counter examples:

(i) [PRO šilker šari bhalolaga-y] ami oi dokan-e giyechi

GEN silk-GEN sari liking -because I this shop-LOC went

'Because I like silk saris I went to this shop'

However, (i) is unlikely to involve PRO. The reason is that the understood GEN-subject can also be phonetically realized. So the empty category seems to be little pro rather than big PRO:

(ii) [amar šilker šaṛi bhalo laga-y] ami oi dokane giyechi

The same holds for non-finite conditional clauses:

(iii) [(amar) barir ranna bhalonalag -le] ami restorant -e khabo I-GEN home-GEN cooking not-liking -if I restaurant-LOC eat-will 'If I don't like the food cooked at home, I'm going to eat in a restaurant' 
paowa ('be hungry') or kanna paowa ('feel like crying') for which my informants are not totally sure whether they may license PRO-subjects. khide peye, bacca cẼcate šuru korlo ('hunger having-gotten, child to cry beginning made', 'having gotten hungry, the child started to cry') does not seem to be bad. Given the overall variation in Case patterns that can be observed among these verbs, the possibility cannot be excluded that such constructions rest on representations which are not in use in finite verb constructions. The general picture that emerges is, nevertheless, that the headfinal language Bengali patterns with head-final German rather than with head-initial Icelandic.

\subsection{Conjunction reduction}

The German examples in (21) and (22) show that Case mismatch between the external arguments of two conjoined clauses is - unlike in Icelandic neither tolerated when the quirky subject precedes the nominative subject nor when the latter precedes the former.

(21) a. *Mich hat gefroren und ich war hungrig me-ACC has frozen and I-NOM was hungry 'I was cold and was hungry'

b. *Ich war hungrig und hat gefroren I-NOM was hungry and me-ACC has frozen 'I was hungry and was cold'

(22) a. *Mir war schlecht und ich konnte nicht aufstehen me-DAT was bad and I-NOM could not up-get 'I was sick and could not get up'

b. *Ich konnte nicht aufstehen und mir war schlecht I-NOM could not up-get and me-DAT was bad 'I could not get up and was sick'

Without deletion, all the examples are grammatical, of course. With deletion, (22b) has the irrelevant reading "I could not get up and was bad (in character etc.)." The predicate schlecht sein ('to be bad') requires nominative Case, and as such the existence of this reading proves that - unlike in Icelandic - only the nominative subject can be deleted.

The same seems to be true in Bengali. The following examples show that nominative and genitive subjects cannot mix in deletion contexts: 
(23)
a. *ami bari theke gElam ar kanna peyeche I-NOM house from went and I-GEN crying came 'I left the house and I felt like crying'
b. *amar kanna peyeche ar ami bari theke gElam I-GEN crying came and I-NOM housefrom went 'I felt like crying and I left the house'

The situation seems to be similar in Hindi (cf. T. Mohanan 1994). Icelandic has means to identify the deletion site across non-matching Cases, while German, Bengali and Hindi must lack such means. We are facing the interesting situation that closely related German and Icelandic differ in this construction, while only remotely related German and Indo-Aryan again show the same restrictions. ${ }^{6}$ I will try to relate the observed differences and similarities to the fact that modern Icelandic is a head-initial language, while Bengali and German are in relevant respects head-final. But before I start with this, let me consider the question whether German nonnominatives can always to be classified as "objects."

\subsection{Are non-nominatives in German always objects?}

We have seen that in German QUIRK-NOM clauses, NOM is the formal subject and thus gets replaced by PRO in infinitives, while in Icelandic QUIRKNOM clauses, QUIRK is the formal subject which thus gets replaced by PRO in infinitives. On the other hand, there seems to be no reason to believe that the semantics of experiencer constructions would be at significant variance in the two languages. In fact, there is overwhelming similarity. Therefore the differences must be rooted in the formal syntactic systems of the languages.

6 Ura (1996: 355), quoting from Lehmann (1993), presents an example from Tamil which may be of relevance in this context. Although the verb's person/number agreement in DAT-NOM clauses is with the nominative, the DAT-subject seems to be able to identify a NOM-subject in a following conjoined clause:
(i) kumaar-ukkuk koopam va -ntu kumaar raajaav-api ati -tt -aan
Kumar-DAT anger-NOM come-PARTIC NOM Raja -ACC beat-PAST-3sg.M
'Kumar got angry and beat Raja'

Ura represents the deleted subject as PRO. So I am not sure whether we are dealing with conjunction at all. I believe we do not. If the example is supposed to mean that a dative subject can control the PRO of an embedded clause, (i) would conform to a widespread pattern (cf. Davison 2002 for Hindi). I would be more surprised if in Tamil a nominative subject could control a dative PRO as in Icelandic. 
It can be demonstrated rather easily that the non-nominative experiencer in German experiencer constructions cannot be objects in the sense of an internal argument. ${ }^{7}$ Consider first quotational forms, i.e., forms which may be listed in a dictionary. While the internal argument may be listed with the infinitive, the external argument would never be. If the external argument is provided at all, a finite verb form would be used. If verbs with a non-nominative experiencer are quoted, the experiencer is missing. Alternatively, a finite verb form ( $3^{\text {rd }}$ person sg.) is used:
a. jemanden suchen someone-ACC search 'to look for someone'
b. jemandem helfen someone-DAT help 'to help someone'
c. *jemanden frieren / jemanden frier $-t$ someone-ACC freeze/someone-ACC freeze -3sg
d. *jemandem grauen / jemandem grau $-t$ someone-DAT disgust / someone-DAT disgust-3sg

Something similar can be observed in nominalizations. The internal accusative either converts to a genitive or is put in a von-PP. Experiencers with accusative Case do not conform to this rule:

(25)
a. Die Polizei sucht die Kinder
the police-NOM seeks the children-ACC
'The police is searching for the children'
b. Das Suchen der Kinder (durch die Polizei)
the searching the children-GEN by the police
c. Das Suchen von den Kindern (durch die Polizei) the searching of the children-DAT by the police

(26)
a. Den Arzt
ekelt
the doctor-ACC disgusts
'The doctor is disgusted'

\footnotetext{
${ }^{7} \mathrm{Cf}$. the discussion of the notion 'external argument' and its relation to quirky subjects in Grimshaw (1990: 33ff.). Relevant remarks are also found in Barðdal (2002: 80), who claims that German and Icelandic are in fact far less different in their quirky constructions than suggested in the established literature.
} 
b. *Das Ekeln des Arztes the disgust the doctor-GEN 'the disgust of the doctor'

(27) a. Den Buben interessiert der Bauernhof the boy-ACC interests the farm-NOM

b. *Das Interessieren des Buben (durch den Bauernhof) the interest-taking the boy-GEN by the farm

c. *Das Interessieren von dem Buben (durch den Bauernhof) the interest-taking of the boy-DAT by the farm

These tests indicate that the experiencer is not an object. The nonnominative experiencer argument rather behaves like an external argument. This finding is corroborated by constituency tests which had been used extensively to argue in favor or against the existence of VP in the early days of GB-theory. One problem at this stage was that in certain situations nominatives behave more like internal than external arguments. The contrast between (28b) and (28c) shows that under conditions of normal accentuation the accusative is "closer" to V than the nominative, and that as a consequence, if topicalization to clause-initial position ("SpecCP") requires single constituency, $\mathrm{ACC}+\mathrm{V}$ may move, but not $\mathrm{NOM}+\mathrm{V} .^{8}$

(28) a. dass die Polizei den Dieb gejagt hat that the police-NOM the thief-ACC chased has 'that the police chased the thief'

b. [Den Dieb gejagt] hat die Polizei

c. ?*[Die Polizei gejagt] hat den Dieb

Consider now experiencer verbs with a single non-nominative argument or with a non-nominative experiencer and a nominative theme/stimulus argument. The judgements reverse:

8 (28c) is perhaps not irreversibly out. With contrastive stress on Polizei and full destressing on Dieb a marked but still grammatical result seems to be yielded. Given VPinternal subjects and scrambling over the subject, this result should not be too surprising. The price that has to be paid before $\mathrm{X}^{\mathrm{n}}$-topicalization is scrambling. I admit that it is difficult to motivate a discourse situation in which the subject would need to be fronted together with the participle. 
(29) a. dass nurden Heiligen bitterlich gefroren hat that only the saint bitterly frozen has 'that only the saint felt bitterly cold'

b. [Bitterlich gefroren] hat nur den Heiligen

c. ?*[Nur den Heiligen gefroren] hat bitterlich

(30) a. dass dem Heiligen vor Ratten nicht gegraut hat that the saint-DAT from rats not disgusted has 'that the saint was not disgusted by rats'

b. [Vor Ratten gegraut] hat dem Heiligen nicht

c. ?*[Dem Heiligen gegraut] hat vor Ratten nicht

These tests show that the non-nominative experiencer may be an external, i.e., "V-distant" argument in the same way as a nominative subject. The contrasts in (31) show that in DAT-NOM clauses, NOM is (normally) closer to $\mathrm{V}$ than the DAT-experiencer:

(31) a. dass dem Heiligen der Streit (schon lange) missfallen hat that the saint-DAT the quarrel-NOM already long displeased has 'that the saint has been displeased by the quarrel for a long time'

b. [Der Streit missfallen] hat dem Heiligen schon lange

c. ?*[Dem Heiligen missfallen] hat der Streit schon lange

The deviance of the c-examples of (29) through (31) may always be a bit weaker than in (28c), but this is exactly a consequence of the markedness of scrambling. Scrambling in agentive constructions is more marked than in experiencer constructions, whatever the reason for this may be. This does not, however, diminish the insight we gain from the distribution of the data: the non-nominative or quirky "subject" behaves like an external argument and not like an object, although - as we have seen - German lacks a stage of subject grammaticalization which Icelandic has attained. The answer to the question in 5.3 is then clearly negative. Nonnominatives in experiencer constructions are external arguments, a feature which they share with their correspondents in Icelandic.

\section{Word order and functional heads}

The GB-system and its immediate successors assumed parametric choices according to which languages can be either head-final or head-initial. This assumption has been discussed controversially since Kayne (1994), where it has been argued that all languages are equal in the sense of an underly- 
ing head-initial ordering with a preceding specifier, and that this ordering may be obliterated by leftward movement such that the ordering headcomplement is linearly changed to complement-head but would in reality be specifier-head (because the complement has been raised into the position of a specifier). I will follow this idea to a certain extent by assuming that only heads which precede their complements are syntactically active functional heads (F). For the time being, I assume that $\mathrm{F}$ can be overt or covert. Covert F can only be visualized, if it attracts lexical material. The process corresponds to traditional head movement to $\mathrm{F}$ versus phrasal movement to SpecFP. Thus, there are three ways for $\mathrm{F}$ to enter the derivation:

(32) a. Lexical F is merged, e.g., Neg, C, functional P (like of)

b. zero $\mathrm{F}$ is merged and attracts a head, e.g., $\mathrm{C}$ in verb-second, little $v$

c. zero F is merged and a phrase is merged into or moved to SpecFP, e.g., in Dutch the expletive er in (1) or a nominative DP. ${ }^{9}$

Chomsky (2001a; 2001b) made the important move to divorce agreement from movement. ${ }^{10}$ Thus, F (the "probe") can agree with X (the "goal") without X necessarily moving to SpecFP. Movement to or base-insertion into SpecFP is triggered by an additional feature: an "EPP-feature." It is not clear how it is motivated (apart from achieving its immediate PFeffect, therefore also called "OCC(urrence) feature"), but let us adopt it for the sake of the argumentation. ${ }^{11}$ Once agreement and movement are disentangled, one begins to see how the system works. In English there are no morphological Cases which could help the syntax-to-semantics mapping. So the grammatical functions have to be detected linearly, and linearity must not be messed up by scrambling. Following Larson's (1988) analysis of the double object construction and its subsequent development into a theory of argument licensing (cf. Hale and Keyser 1993), I assume that the verb undergoes a series of head movements, thus licensing its arguments. The important point here is that the verb establishes a pre-VP functional position $\mathrm{T}$ with an EPP-feature. This defines the landing site of the nomi-

9 Notice that we have to assume a zero head because Dutch is still V-final, i.e., under my assumptions the verb does not identify SpecFP.

10 See also Borer's (1986) notion of an "I-subject," i.e., an NP which is coindexed with Infl in the accessible domain of Infl but does not necessarily occupy the $[\mathrm{NP}, \mathrm{S}]$ position.

11 For an interesting suggestion cf. Rosengren (2002). Rosengren sees the EPP as a parameterized visibility requirement on SpecFinP or SpecTP which yields semantic differences when an expletive is inserted in these positions. 
native DP, there and other locative phrases like into the room being the only remaining alternatives.

Icelandic, for comparison, does have a reasonable system of morphological Case. Given that the morphological Cases trivialize the syntaxto-semantics mapping, and the finite verb agrees with the nominative without movement, there appears to be no prima facie reason for the external argument to undergo movement to SpecTP. On the other hand, if the functional head $\mathrm{T}$ has an EPP-feature, there is no deeper reason why this feature could not be checked by an argument with quirky Case. The situation is essentially the same as in Old English where due to the system of morphological Case, EPP-checking by a non-nominative DP does not obliterate grammatical relations:

(33) pam cynge licodon peran the king-DAT pleased-PL pear-PL

'To the king pears were pleasing', 'The king liked pears' (Lightfoot 1979)

We see the importance of an initial functional head $\mathrm{F}$ for the definition of a position which arises due to the presence of an EPP feature. The EPPfeature demands that SpecFP be syntactically realized.

We will turn to a discussion of final functional heads and their syntactic status. Before doing so in 6.2, however, it is necessary to give an idea of how arguments are ordered in a quasi pre-syntactic fashion, i.e., what the principles are that regulate our intuitions about unmarked word order. This will be done next.

\subsection{Universal ordering}

There is evidence for cross-linguistic principles of constituent ordering that apply independently of the functional vocabulary of a given language. All other things being equal, arguments with an animate referent precede arguments with an inanimate referent, agents precede non-agents, definites precede indefinites, clitics precede non-clitics, "old" information precedes "new" information, etc. The working of such ordering constraints has been described for German in detail in Lenerz (1977) and in much subsequent work on word order. It has recently been recast in an optimality theoretic approach by Müller (1999; 2000). For a cross-linguistic and more typologically oriented account see Primus (1999). All these approaches broadly converge on ordering principles and preferences which include the ones in (34). ( $\mathrm{X}$ "Y means that $\mathrm{X}$ linearly precedes $\mathrm{Y}$ ). 


\begin{tabular}{|l|l|}
\hline ANIMACY & ANIMATE « INANIMATE \\
\hline HUMANNESS & HUMAN « NON-HUMAN \\
\hline THETA HIERARCHY & AGENT « EXPERIENCER « THEME « ... \\
\hline DEFINITNESS & DEFINITE « INDEFINITE \\
\hline PHONOLOGICAL WEIGHT & CLITIC « NON-CLITICS \\
\hline INFORMATION PACKAGING & OLD INFORMATION « NEW INFORMATION \\
\hline
\end{tabular}

These ordering principles often conspire, and they sometimes do not fully resolve an ordering problem. In a system of drastically impoverished morphological Case such as English, animacy is violated in favor of harder principles of structural Case licensing. So we get The sun disturbs Harry instead of the expected *Harry disturbs the sun. In German, cliticization would, for instance, win over animacy, as seen in dass'se den Mann stört ('that it (e.g. the sun) the man-ACC disturbs'). In languages with morphological Case, all other things being equal, animacy becomes decisive, however. Thus, the preferred order in German experiencer constructions with ACC or DAT Case on the experiencer and NOM on the theme/stimulus is as in the following examples: ${ }^{12}$
a. dass den Vater der Streit anödet that the father-ACC the quarrel-NOM bores 'that father is bored by the quarrel'
b. dass dem Vater der Streit missfällt that the father-DAT the quarrel-NOM displeases 'that father is fed up with the quarrel'

Although agreement holds between the finite verb and the nominative, the nominative will - all other things being equal - remain the lower argument. For reasons which will become clear in the next section, we assume that German lacks an EPP-feature on T. If this is true, there is no need for either of the two DPs to raise to SpecTP or to any other functionally defined landing site of this sort. If the relation AGREE is independent of movement, it is expected that the universal ordering ANIMATE « INANIMATE is projected directly into syntactic structure by the operation MERGE.

12 Similar sentences are even clearer in Icelandic. While German may blur the picture by scrambling, Icelandic - not being a scrambling language - relies on DAT-NOM or ACCNOM order entirely. 
I conclude that argument structure observes universal ordering principles which exist independently of language particular principles of Case licensing. To the extent that this ordering can be projected directly (as I expect is the case in a language with head-final VP), Case-linking is trivialized by the fact that each Case can be licensed without displacement.

\subsection{Initial versus final functional heads}

Given that universal ordering in the sense of section 6.1 holds, closely related Germanic languages with morphological Case like German and Icelandic are expected to show the observed similarity in the projection of argument structure. The Bengali data which have been considered, point in the same direction, i.e., non-nominative NPs/DPs can bear the higher argument role under the condition that the other argument is a nonvolitional argument etc. Under these conditions it must be explained why Icelandic is special in licensing non-nominative arguments with the highest role as formal subjects while German and Bengali do not. I want to argue that this difference reduces to the fact that Icelandic has developed head-initial ordering which includes a syntactically active initial functional head by which the closest argument, here the quirky subject, will be attracted.

The diachronic shift from a head-final VP to a head-initial VP which occurred in Germanic had deep-rooted consequences, the most prominent perhaps being that this development involved or was even driven by the reorganization of the functional vocabulary of the language. ${ }^{13}$ Head-initial languages usually show a VP-initial functional head (or set of heads) which must be visualized by a phrase that fills its specifier. While this phrase is the nominative subject in English, an expletive there or, in rarer cases, a locative PP, the choice can be more diverse in a language with a morphological Case system such as Icelandic. In Icelandic, any argument which bears the highest argument role may serve the function of checking the EPP-feature of $\mathrm{T}$ (assuming simply this as the highest functional position of IP for the moment). Sigurðsson (2001) argues that "NP-movement 'interprets' more than one feature", i.e., movement to the specifier position presumably has consequences that go beyond EPP-

13 See Kiparsky (1996) for relevant discussion from a diachronic perspective. Rosengren (2002) argues that the EPP is "in the service of semantics," and that languages which achieve the same semantic effects by scrambling do not (necessarily) attend to the EPP. German is such a language, and more strictly head-final languages such as Bengali are, too. 
checking per se. We will turn to the evidence for such other features in the next section. Before doing so we turn to the question why head-final languages (or rather languages with a head-final VP) give no conclusive evidence for a syntactically active functional head. ${ }^{14}$

Reconsider (32a-c). (32a) may be true of head final phrases, the only difference being that a functional head $\mathrm{F}$ would be merged to the right of the phrase. (32b) is problematic, however. Since V, $v$ and T are strictly adjacent due to morphological structure, and since adjacent verbs always form a V-cluster, the assumption of V-to-I (or V-to- $v$-to-T) raising remains a purely academic issue. Movement would always be stringvacuous. It could be equally true that I (or $v$ and $\mathrm{T}$ ) are generated as features of a finite transitive V. (Cf. Bayer \& Kornfilt 1990; 1994 for German; Reuland, 1990; Reuland \& Kosmeijer 1988 for Dutch). In this case, the feature complex $\{\mathrm{V}+v+\mathrm{T}\}$ would formally license arguments under $\mathrm{m}$ command. We will shortly see that $\mathrm{m}$-command is independently needed. (32c) fares even worse. If a zero functional head $F$ is merged which has to be visualized by an XP moving into SpecFP, the natural expectation would be to see movement to the right. This would square with Kayne's (1994) conjecture that specifiers must be adjacent to their heads. In head-final structures the specifier would thus have to be to the right of the head: Complement-Head-Specifier. Among the languages of the world, there seems to be close to no evidence for such a structure, however. If the specifier is merged on the left side, the complement intervenes, and given that the complement can be of unbounded length, head-visualization via spec-head agreement looks like a computationally implausible option.

In addition to this, a number of arguments have been presented which show that the assumption of a mirror-image of the IP-structure [ ${ }_{\text {IP }} \ldots$

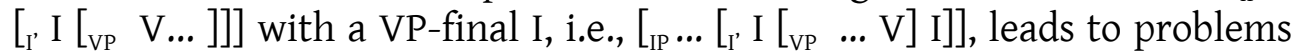
that can be avoided, if there is no phrase structural difference between pure V-projections and I-projections. As pointed out in Haider (1993), one obvious problem concerns extraposed elements. If VP is disconnected from auxiliaries that have moved to I, one would expect extraposed or otherwise adjoined material between VP and Aux. Such structures are, however, completely ill-formed. Alternatively, extraposed material would have to adjoin to I'. But even this would not avoid the problem that extraposed clauses usually appear to be "lower" than expected under adjunc-

14 I do not want to claim that German lacks VP-initial functional heads entirely. There is, for example, good evidence that sentential negation is articulated in such a way that the morpheme of negation nicht heads a NegP, and that negative quantifier move to its specifier. This is especially clear in dialects like Bavarian which show the negative concord phenomenon. For details cf. Bayer (1997) and Weiß (1999). 
tion to IP or I'. This is demonstrated by binding into such clauses. (Cf. Haider 1994; Bayer 1996; 1999 for German as well as for Bengali). Further arguments against V-to-I in German (and other OV-languages) which cannot be reviewed here appear in Vikner (2001: ch.3). Haider (1993; 2000a) argues that in head-final languages the verb's features for tense and agreement are added in the lexicon and project jointly with the lexical verb. Thus, the finite verb may discharge arguments licensed by it regressively along the span of VP. Licensing is achieved by successive operations of MERGE. In particular, no verb movement is required which would establish functionally defined positions for specifiers, as expected under (32c). In head-initial languages, instead, the verb has to discharge its arguments progressively by raising to intermediary verbal heads in a Larson-type shell structure. More in line with recent developments, I assume here that government (to the right) can be replaced by checking in derived (specifier) positions. The difference between SOV- and SVO-licensing is shown in (36) where we mark the functional vocabulary with F, F ranging over $v, \mathrm{~T}$, AGR etc., and where the lexical fusion of $V$ and $F$ is symbolized with curly brackets.

(36) a. "Regressive" licensing in a head-final VP

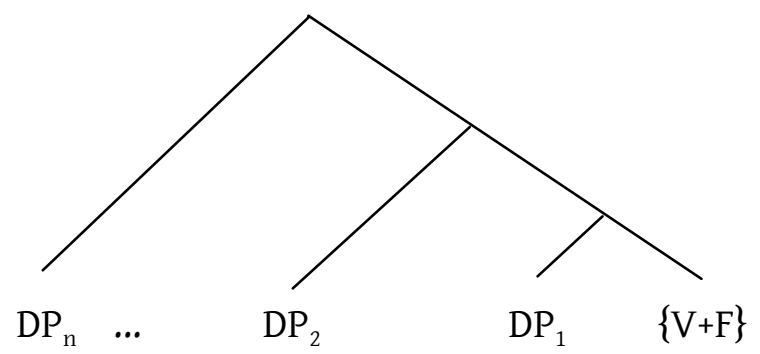


b. "Progressive" licensing in a head-initial VP

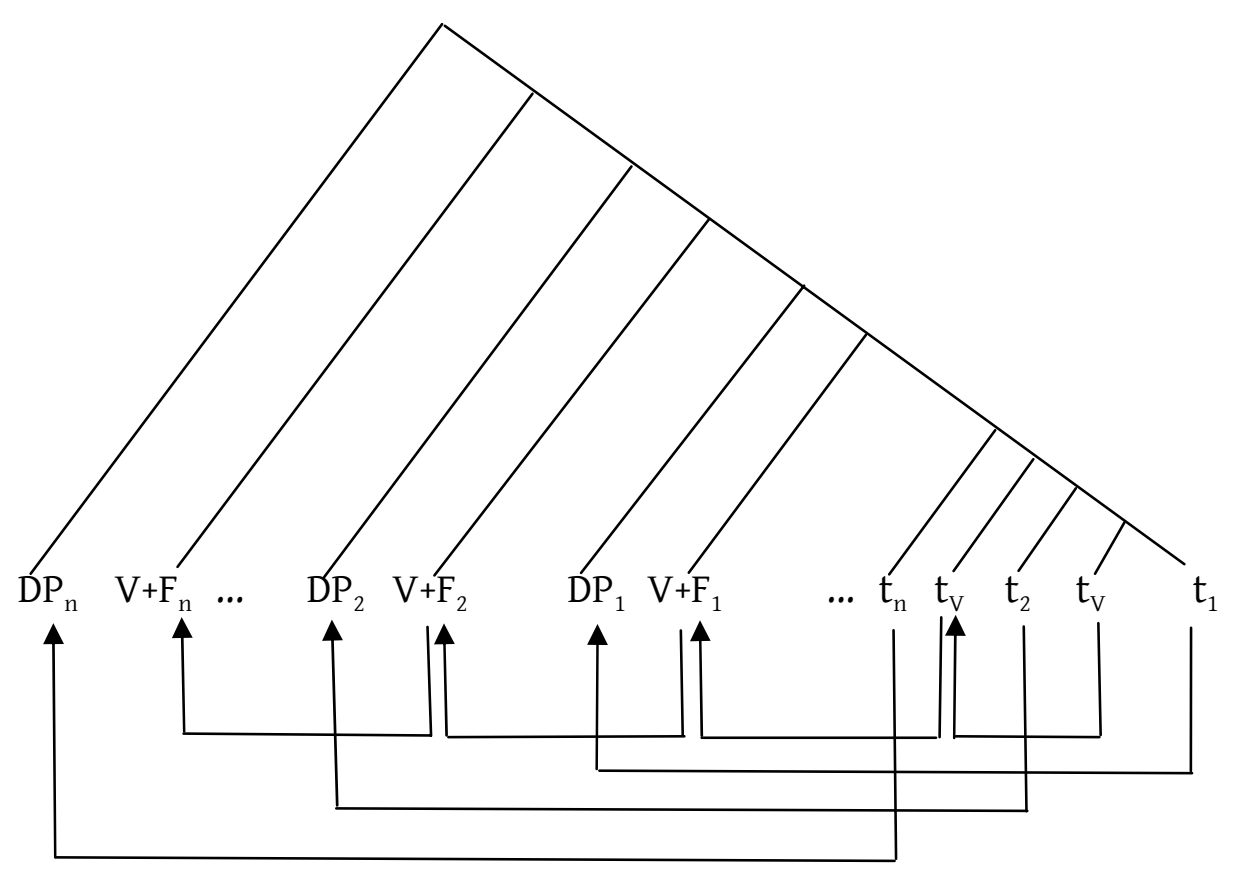

Given this, Haider's (2000b) claim that SOV is "more basic" than SVO is certainly on the right track. (36a) suggests that there is a single "big" local domain in which AGREE can operate, whereas (36b) suggests that there is a series of "small" local domains - characterized for the present purpose as spec-head relations - in which AGREE holds between $\mathrm{F}$ and the element to its immediate left. In (36b) displacement is driven by an EPP-feature on F which requires overt movement into its specifier. While I do not intend to claim that this is what happens in SVO-languages in general, I want to maintain that this is at least true for the highest argument as defined by argument structure. Nothing of this sort is required in (36a). If $\mathrm{V}$ and $\mathrm{F}$ enter the syntax as a lexically complex item, and there is no requirement of EPP-checking, the features associated with F can be checked as soon as the phrase structure unfolds by MERGE. The important aspect for the present purposes is that the external argument is not displaced by EPP-checking.

We have so far assumed that the relation AGREE holds between features of the verb and corresponding arguments which check these features. But AGREE has been defined as a probe-goal relation in which the probe c-commands the goal. The exact opposite is the case in (36a). In 
(36a) the goal must be reached by a probe which is lower. Provided that AGREE operates in the maximal domain of $\{\mathrm{V}+\mathrm{F}\}$, what Haider calls "regressive" licensing is tantamount to agreement under m-command. Case checking can take place anywhere in the maximal projection of $\{\mathrm{V}+\mathrm{F}\}$ in (36a) and is not confined to specific positions in the phrase marker.

Can m-command be independently motivated? There is striking evidence for this relation that comes from negation in Bengali and similar head-final languages. The central point is that negative polarity items (NPIs) in these languages may both precede and follow the morpheme of negation which is arguably part of the verbal complex. For details about Bengali cf. Bayer (2001: § 3.5) where it is pointed out that NPI-licensing under $\mathrm{m}$-command is not only the simplest but also the only viable solution because NPIs refuse to undergo reconstruction. Thus, there is promising empirical evidence that head-final languages employ $\mathrm{m}$-command anyway.

\subsection{The derivation of subjecthood}

On the basis of the previous considerations we can now flesh out the intuition that a non-nominative or "quirky" subject is sometimes more and sometimes less subject-like, and that this is a consequence of the order of constituents as dictated by the functional vocabulary.

In German and other OV-languages, formal subjecthood is obviously achieved by agreement with the finite verb. The formal subject is the one which agrees with the finite verb. Since agreement is independent of EPP-checking, it may take place in the entire local domain of the inflected verb, i.e., under m-command. EPP-checking cannot be universal, a conclusion that has been reached for independent reasons in earlier work such as Fanselow (1991) and Brandner (1993). Comparing German and Bengali, the following can be said about agreement: (i) In German, there is agreement in number and person, while in Bengali, there is no agreement in number. Both languages have a system of honorificity, the Bengali system being more elaborate than the German system. Agreement covers this feature as well, but it is always the nominative argument which agrees, never the dative or genitive. ${ }^{15}$ (ii) Both languages have "subjectless" sentences, i.e.,

15 Modern German has a two-way distinction of intimate/polite which is confined to $2^{\text {nd }}$ person. Bengali has a three-way distinction of inferior/equal/superior which holds in $2^{\text {nd }}$, and a two-way distinction of equal/superior in $3^{\text {rd }}$ person. In fact, even $3^{\text {rd }}$ person uses a three-way pronominal distinction but only a binary agreement distinction. In comparison to this, Korean and Japanese employ a rather different system of subject-honorification. In these languages it is surprisingly the dative subject which "agrees" with the verb. However, 
sentences in which the only visible argument bears quirky Case. In this situation the verb's agreement is $3^{\text {rd }}$ person/singular, which is generally considered to be the default value. (iii) As we have already seen, there is clear evidence that in German infinitives only the nominative argument is replaced by PRO, PRO being the infinitival realization of nominative Case rather than a non-Case. As far as I know, other head-final languages behave alike, i.e., they do not show quirky PRO. Given principles of universal ordering by virtue of argument structure, it is expected that the highest argument according to this kind of ordering does not always coincide with the formal (nominative or zero) subject as identified by agreement. Since quirky subjects in these languages behave like external arguments to which a predicate is applied, it is certainly not inappropriate to call the external arguments "subject." ${ }^{16}$ However, these "subjects" are defined on a semantic basis. They lack any kind of formal licensing.

How is subjecthood derived in Icelandic? Being a head-initial language, Icelandic has a pre-VP functional head $\mathrm{F}$ into whose specifier the highest argument is moved, be it a nominative or a non-nominative NP/DP. Although Icelandic is mainstream in showing agreement with the nominative-bearing NP/DP, there is evidence for agreement to be split into number and person agreement, as has been pointed out by Taraldsen (1995), Boeckx (2000) and Sigurðsson(2001; 2002). The data in (37) are taken from Sigurðsson(2001: 144).

\footnotetext{
some caution is necessary here because there is no person, number or Case agreement in these languages, and in Japanese the HON-morpheme is a prefix on the verb. Contrary to Ura (1996; 1999), I would not assume that Japanese and Korean have a functionally defined spec-position (SpecTP) into which the dative subject has to move for reasons of EPPchecking and agreement with the verb.

16 Since quirky subjects are NPs/DPs with inherent Case, it is not obvious that they can enter a predication relation. As Bayer et.al. (2001) have argued, German datives are DPs which are dominated by an extra layer of KASE, i.e., they are KPs; and in this sense they have much in common with PPs. Probal Dasgupta (p.c.), quoting from a 1983 lecture by Richard Kayne, suggests that there is a form of predication in which a quirky subject has the analogue of a P-shell - perhaps what Bayer et al. (2001) call a KP -, and the predicational indexing holds between $\mathrm{P}$ and the predicate rather than between the straight NP/DP and the predicate. Indeed examples of this sort are found even in English. The best known case is perhaps Under the bed is a good place to hide where the semantics clearly demands that it is not the bed but the space under the bed that serves as the subject of the predicate. For promising developments and expansions of this idea to which I cannot turn here for reasons of space c.f. Landau (2002).
} 
(37)
a. ${ }^{*}$ Mer höfðum leiðst við
me-DAT had (1pl) bored we-NOM
'I had found ourselves boring'
b. *Mer
höfðuð leiðst pið
me-DAT had (2pl) bored you-NOM
'I had found you boring'
c. Mer höfðu leiðst peir
me-DAT had (3pl) bored they-NOM
'I had found them boring'

The (VP-internal) nominative agrees with the finite verb only in (37c), i.e., in a situation where the nominative argument is $3^{\text {rd }}$ person or - in Sigurðsson's theory - "non-person." Whenever it is $1^{\text {st }}$ or $2^{\text {nd }}$ person ("real person") as in (37a,b), agreement is blocked. In German there is no such constraint, i.e., there is unrestricted person agreement with the nominative: ${ }^{17}$
a. Dass ihr
nur wír
missfallen haben
that her-DAT only we-NOM displeased have(1pl)
'that she was only displeased with us'
b. Dass ihm nur îhr missfallen habt
that him-DAT only you-NOM displeased have (1pl)
'that he was only displeased with you $\mathrm{pl}^{\text {' }}$

Sigurðsson interprets the Icelandic data in (37) as follows: With respect to $3^{\text {rd }}$ person there is no true person agreement; as a consequence, there is only number agreement, and number agreement is always with the nominative. The finite verb undergoes $3^{\text {rd }}$ person default agreement with the quirky subject. But since this non-person agreement has taken away the possibility of agreement for "real" person, person agreement with the nominative is blocked. Person agreement being trivialized, there is only number agreement with the nominative. The situation is depicted in (39):

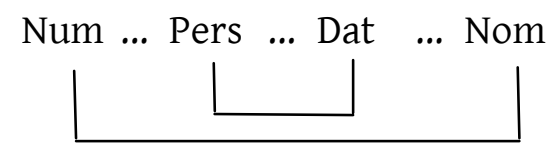

17 The test cannot be made in Bengali because "dative subject" constructions require an accusative object, not a nominative. Thus, there is only $3^{\text {rd }}$ person default agreement in this language. I could not come up with data which would make this question accessible. 
Sigurðsson's analysis, which hinges on very specific assumptions about person (non-)agreement, gains plausibility, if one takes the proposal by Bayer et.al. (2001) into account that datives are more than DPs, namely $\mathrm{K}$ (ase) Phrases. Datives share much with PPs, as has been observed time and again. Most importantly, there is no agreement between a (locative) $\mathrm{PP}$ and the verb. If quirky subjects of all non-nominative Cases turn out to be KPs which force the selection of $3^{\text {rd }}$ person default agreement, the Icelandic facts would constitute rather striking evidence for split agreement in Sigurðsson's sense. The important point is the difference between Icelandic and the closely related language German. As the German data in (38) show, person agreement goes hand in hand with number agreement. This is expected under the assumptions about clause structure expressed in (36). There is no designated position in which the external argument could undergo agreement on the basis of EPP-checking. As a result, the person feature is activated together with the features for number and tense, all of which are part of the finite verb. In Icelandic, the VP-initial functional head must be checked by the highest argument which moves into its specifier. As Sigurðsson(2002a) puts it, it seems that there is an EPP-feature for person which excludes number.

To account for the difference between German and Icelandic DATNOM experiencer constructions, Sigurðsson (2002b) suggests the structures in (40) which I took the liberty of changing in some irrelevant detail:

$$
\begin{aligned}
& \text { a. Icelandic } \\
& \left.\left.\left[{ }_{C P} C^{0}\left[{ }_{\text {PersP }} \text { Pers }^{0}{ }_{\text {NumP }} \text { DAT }_{i}\left[{ }_{\text {Num' }} \text { Num }^{0} \ldots{ }_{v \mathrm{P}} t_{i} \ldots \text { NOM... }\right]\right]\right]\right]\right] \\
& \text { b. German }
\end{aligned}
$$

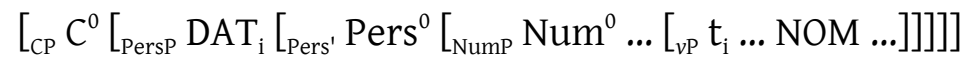

The dative subject raises to NumP in Icelandic where it is close enough to Pers $^{0}$ to agree with it via immediate c-command. This gives rise to what Sigurðsson calls the Dative Intervention Effect. Pers ${ }^{0}$ cannot agree with then nominative because it is already busy with the dative. If true, why should this effect be absent in German? Due to some parametric variation, the dative is said to raise higher in German than in Icelandic, namely to the left of Pers (in fact not exactly to SpecPersP as suggested by (40b)) such that the nominative is controlled by both person and number agreement. Thus, Pers ${ }^{0}$ must agree with the nominative, while such agreement is broken in Icelandic due to the dative that intervenes between $\operatorname{Pers}^{0}$ and the nominative. The question is why such a parametric variation should exists. Sigurðsson explicitly excludes other explanations such as Haider's (2000b) 
suggestion to derive these differences from the head-final order of the verbal projection and its consequences for phrase structure.

In the absence of empirical support for the suggested parametric variation (between two closely related and highly comparable Germanic languages), I cannot accept this as an explanation because rather the problem is only shifted to another area. My own answer is in principle compatible with Sigurðsson's account of Icelandic, but suggests a rather different - in my view more radical but also less ad hoc - explanation for the difference between the two languages: German lacks any of the functional positions in the extended verbal domain which would invite EPP-checking. Thus, the quirky external argument which has subject properties for essentially semantic reasons cannot turn into a grammatical subject as the nominative does due to agreement with the verb. Notice that this rather huge difference follows from something rather small: the syntactic (de-) activation of morphological features of the inflected verb.

\section{The squishiness of the notion subject}

It is often said that a certain constituent is more "subject-like" than another one. This suggests that the notion subject is somehow gradable. The present account provides a perspective of how to make this impression precise. We have seen that German and Icelandic are very similar in their Case systems and in their quirky-subject constructions, but that they differ in important features by which quirky subjects acquire properties of grammatical subjects. What is the common denominator then? Dasgupta (2001) speaks of "substantive agreement" versus "formal agreement," the former being defined on a purely semantic basis of predication, the latter being defined on the basis of featural identity. By extension, we can speak of subjects as SUBSTANTIVE SUBJECTS and FORMAL SUBJECTS. Very often the formal subject coincides with the substantive subject, but German offers lots of examples where this is not true. Of relevance are cases in which the only role of a human non-agent is linked to accusative or dative Case as in (9a,c), and cases in which the higher role is linked with dative or accusative Case, while the lower role - often an inanimate object - is linked with nominative Case. Among languages with a sufficiently rich array of morphological Cases, this is a very frequent and very typical property. of course, Icelandic falls perfectly into this set. What makes Icelandic special is the fact that the quirky subject undergoes movement for the reason of EPP-checking, and that the affiliation with a functionally based specifier position seems to have repercussions in the agreement system. 
The distinction at hand leads to a decomposition of the notion "subject" according to which rather diverse factors may be responsible for the more or less subject-like behavior of certain arguments. I share with Wunderlich (2001) the conclusion that (i) the notion subject, taken as a theoretical primitive, "does not have much explanatory force," and that (ii) "the syntax of Icelandic requires a designated argument in the preverbal position, contrary to German [and the better studied head-final languages, JB], which does not have such a position". ${ }^{18}$

\section{Conclusion}

We have presented data mainly from German and Icelandic but also from Bengali and - more marginally - from other languages which highlighted differences that had received much attention in recent years, but have not led to homogeneous conclusions among the different streams of syntactic research. The central point is that German and Icelandic are closely related Germanic languages with each retaining a four-ways system of morphological Case but differ significantly in their syntax of argument licensing. While German treats only nominatives as formal subjects and allows only correspondents of nominatives to be nullified in infinitives, Icelandic shows non-nominative ("quirky") subjects which partially behave like formal subjects and are nullified in infinitives. We have argued that this difference can be accounted for on the basis of another difference between these two languages: German has a head-final VP, Icelandic a head-initial VP. These differences in word order are associated with different implementations of the VP-relevant functional vocabulary. Icelandic has a preverbal functional head (or a set of such heads) which - due to Relativized Minimality - attracts the highest argument of the VP (or $v \mathrm{P}$ ) in order to

18 Given the adoption of (ii), I do not quite understand why Wunderlich insists on the addition of various constraints by the ranking of which German and Icelandic are supposed to diverge. To account for the differences in control structures he proposes a constraint *NOM-INF by which a nominative argument is banned from an infinitival clause, and a constraint SEMHIER by which the semantically highest argument is banned from an infinitival clause. German is said to observe the ranking *NOM-INF $>>$ SEMHIER, while Icelandic attends to the ranking SEMHIER $>>*$ NOM-INF. This leads to the rather astonishing conclusion that "semantics turns out to be more important in Icelandic than in German, while the morphosyntactic marking turns out to be more important in German than in Icelandic". According to my own research, no such constraints are needed (or even desirable). My impression is rather that the semantic hierarchy is universally valid, and that its projection in syntax is dependent on the system of morphological Case and the implementation of the functional vocabulary. 
satisfy the EPP. We have argued that it is this property that leads to a "grammaticalization" of the highest argument in the sense of a formal subject. Following important work by Hubert Haider, we have argued that German (like presumably all head-final languages) does not simply employ a mirror-image of the English/Icelandic IP-architecture. Rather, the difference is that head-final languages do not project a functionally defined specifier such as SpecIP, Spec-AgrP, SpecTP etc. Checking is rather performed hand in hand with MERGE, i.e., without displacement. Checking in this way is possible, if the verb encodes its functional features morphologically and agrees with its arguments via m-command. This does not give a non-nominative external argument a status with privileges beyond the status assigned to it by argument structure. So the only argument that enjoys such a privilege is the one that is picked up by agreement anyway: the nominative.

A more general result of this study is that the notion subject is either too narrow (as in GB-theory) or too wide (as in functional accounts). The present proposal can integrate central insights from semantic hierarchy approaches (cf. Primus 1999) into a framework of merging and feature checking with the result of a more differentiated landscape of properties of subjecthood. The central issue seems to be to find the point where semantically rooted substantive properties meet with properties of formal licensing. If this can be achieved, what traditional as well as formal grammar has identified as "subject" may decompose into a number of interacting but distinct forces. To the extent that this program of research can be carried out successfully, the notion "subject" can be relegated to the realm of linguistic façon de parler.

\section{Acknowledgements}

I wish to thank audiences at the Universities of Cologne and Tübingen as well as Tokyo University where parts of this research have been presented in talks. For help with discussion and data questions I am indebted to Jogamaya Bayer, Balthasar Bickel, Alice Davison, M.T. Hany Babu, Peter Hook, K.A. Jayaseelan, Aditi Lahiri, Uli Lutz, Beatrice Primus, Gautam Sengupta, Halldór Sigurðsson, K.V. Subbarao and Dieter Wunderlich. No shortcomings of this work must be blamed on any of them. Special thanks to Peri Bhaskararao and the Japanese Ministry of Education, Science, Sports and Culture for making my visit to Tokyo possible. 


\section{References}

Andrews, A. 1976. "The VP complement analysis in modern Icelandic". NELS 6: 1-21

Barðdal, J. 2002. “'Oblique subjects' in Icelandic and German”. Working Papers in Scandinavian Syntax 70: 61-99.

Bayer, J. 1996. Directionality and Logical Form: On the Scope of Focusing Particles and WH-in-situ. Dordrecht: Kluwer.

Bayer, J. 1997. "Word order in Bavarian multiple negation". 9. Wuppertaler Linguistisches Kolloquium, 20.-21. November 1997.

Bayer, J. 1999. "Final complementizers in hybrid language”. Journal of Linguistics 35: 233-271.

Bayer, J. 2001. "Two grammars in one: Sentential complements and complementizers in Bengali and other South Asian languages". In The Yearbook of South Asian Languages: Tokyo Symposium on South Asian Languages Contact, Convergence and Typology, P. Bhaskararao and K.V. Subbarao (eds.), 11-36. Sage Publications, New Delhi.

Bayer, J., M. Bader and M. Meng. 2001. "Morphological underspecification meets oblique case: syntactic and processing effects in German". Lingua 111: 465-514.

Bayer, J. and J. Kornfilt. 1990. "Restructuring effects in German”. In Parametric Variation in Germanic and Romance. Proceedings for a DYANA Workshop. September 1989, E. Engdahl, M. Reape, M. Mellor and R.P. Cooper (eds), 21-42. Edinburgh Working Papers in Cognitive Science 6. University of Edinburgh.

Bayer, J. and J. Kornfilt. 1994. "Against scrambling as an instance of movealpha”. In Studies on Scrambling, H. van Riemsdijk and N. Corver (eds), 17-60. Berlin: De Gruyter.

Bierwisch, M. 1990. "Verb cluster formation as a morphological process". In Yearbook of Morphology 3, G. Booij and J. van Marle (eds), 173-199. Foris: Dordrecht.

Boeckx, C. 2000. “Quirky agreement”. Studia Linguistica 54: 354-380.

Borer, H. 1986. "I-subjects". Linguistic Inquiry 17: 375-416.

Brandner, E. 1993. "The projection of categories and the nature of agreement". In The Parametrization of Universal Grammar, G. Fanselow (ed.), 73121. Amsterdam: Benjamins.

Cardinaletti, A. 1998. "Pronouns in Germanic and Romance languages: an overview". In Clitics in the Languages of Europe, H. van Riemsdijk (ed.), 3582. Berlin: de Gruyter.

Chomsky, N. 2001a. "Derivation by phase". In Ken Hale: A Life in Language, M. Kenstowicz (ed.), 1-52. Cambridge, MA: MIT-Press.

Chomsky, N. 2001b. "Beyond explanatory adequacy". Ms., MIT. 
Dasgupta, P. 2001. "Some non-nominative subjects in Bangla". This volume.

Davison, A. 2002. "Non-nominative subjects in Hindi/Urdu: VP structures and case parameters". This volume.

Fanselow, G. 1991. Minimale Syntax. Groninger Arbeiten zur Germanistischen Linguistik 32.

Fischer, S. 2002. "The diachronic relationship between quirky subjects and stylistic fronting". This volume.

Grimshaw, J. 1990. Argument Structure. Cambridge, MA: MIT-Press.

Haider, H. 1993. Deutsche Syntax generativ. Tübingen: Gunter Narr Verlag.

Haider, H. 1994. "Detachment - the later, the deeper". Working Paper \#41 of the Sonderforschungsbereich 340 (Universities of Stuttgart and Tübingen).

Haider, H. 2000a. "Branching and discharge". In Lexical Specification and Insertion, P. Coopmans, M. Everaert and J. Grimshaw (eds), 135-164. Amsterdam: Benjamins.

Haider, H. 2000b. "OV is more basic than VO". In The Derivation of VO and OV, P. Svenonius (ed.), 45-67. Amsterdam: Benjamins.

Hale, K. and S.J. Keyser. 1993. "On argument structure and the lexical expression of syntactic relations". In The View from Building 20, K. Hale and S.J. Keyser (eds), 53-109. Cambridge, MA: MIT Press.

Jaspers, D. 1989. "A head position for Dutch clitics, or: Wilma, Wim and Wackernagel". In Sentential Complementation and the Lexicon. Studies in Honor of Wim de Geest, D. Jaspers, W. Klooster, Y. Putseys and P. Seuren (eds), 241-252. Dordrecht: Foris.

Jayaseelan, K.A. 1990. "The dative subject construction and the pro-drop parameter". In Experiencer Subjects in South Asian Languages, M.K. Verma and K.P. Mohanan (eds), 269-283. Stanford: CSLI Publications.

Jayaseelan, K.A. 1998. Parametric Studies in Malayalam Syntax. New Delhi: Allied Publishers.

Jayaseelan, K.A. 2002. "The possessor/experiencer dative in Malayalam". This volume.

Kaiser, G. 2002. "Syntaktische Variation und generative Syntaxtheorie". To appear in Syntaxtheorien: Modelle, Methoden, Motive, E. Stark and U. Wanduszka (eds). Tübingen: Narr.

Kayne, R. 1994. The Antisymmetry of Syntax. Cambridge, MA: MIT-Press.

Kiparsky, P. 1996. "The shift to head-initial VP in Germanic". In Studies in Comparative Germanic Syntax II, H. Thráinsson, S. Epstein and S. Peter (eds), 140-179. Dordrecht: Kluwer.

Klaiman, M. 1980. "Bengali dative subjects". Lingua 51: 275-295.

Landau, I. 2002. "The locative syntax of experiencers". Talk presented at IATL 18. 
Larson, R. 1988. "On the double object construction". Linguistic Inquiry 14: 223-249.

Lehmann, T. 1993. A Grammar of Modern Tamil. Pondicherry: Pondicherry Institute of Linguistics and Culture.

Lenerz, J. 1977. Zur Abfolge nominaler Satzglieder im Deutschen. Tübingen: Gunter Narr Verlag.

Lightfoot, D. 1979. Principles of Diachronic Syntax. Cambridge: Cambridge University Press.

Mohanan, T. 1994. Argument Structure in Hindi. Stanford, CA: CSLI.

Müller, G. 1999. "Optimality, markedness, and word order in German”. Linguistics 37: 777-818.

Müller, G. 2000. Elemente der optimalitätstheoretischen Syntax. Tübingen: Stauffenburg-Verlag.

Primus, B. 1999. Cases and Thematic Roles: Ergative, Accusative and Active. Tübingen: Niemeyer.

Raposo, E. and J. Uriagereka. 1990. "Long disctance Case assignment". Linguistic Inquiry 21: 505-537.

Reuland, E. 1990. "Head movement and the relation between morphology and syntax". In Yearbook of Morphology 3, G. Booij and J. van Marle (eds).129-161.

Reuland, E. and W. Kosmeijer. 1988. "Projecting inflected verbs". Groninger Arbeiten zur Germanistischen Linguistik 29: 88-113.

Rosengren, I. 2002. "EPP: A syntactic device in the service of semantics". Studia Linguistics 56: 145-190.

Sigurðsson, H. 1989. Verbal Syntax and Case in Icelandic. Doctoral dissertation, University of Iceland, Reykjavík.

Sigurðsson, H. 2000. "To be an oblique subject: Russian vs. Icelandic". Working Papers in Scandinavian Syntax 66: 1-32.

Sigurðsson, H. 2001. "Case: abstract vs. morphological”. Working Papers in Scandinavian Syntax 67: 103-151.

Sigurðsson, H. 2002a. "Icelandic non-nominative subjects: facts and implications". This volume.

Sigurðsson, H. 2002b. "Agree and agreement: Evidence from Germanic". Working Papers in Scandinavian Syntax 70: 101-156.

Taraldsen, T. 1995. "On agreement and nominative objects in Icelandic". In Studies in Comparative Germanic Syntax, H. Haider, S. Olsen and S. Vikner (eds), 307-327. Dordrecht: Kluwer.

Ura, H. 1996. Multiple Feature Checking: A Theory of Grammatical Function Splitting. PhD dissertation, MIT.

Ura, H. 1999. "Checking theory and dative subject constructions in Japanese and Korean". Journal of East Asian Linguistics 8: 223-254. 
Vikner, S. 2001. Verb Movement Variation in Germanic and Optimality Theory. Habilitation thesis, University of Stuttgart.

Wali, K. and O. N. Koul. 1997. Kashmiri. London: Routledge.

Weiß, H. 1999. "Duplex negatio non semper affirmat". Linguistics 37: 819846.

Wunderlich, D. 2001. "The force of lexical case: German and Icelandic compared". Ms., University of Düsseldorf.

Zaenen, A., J. Maling and H. Thráinsson. 1985. "Case and grammatical functions: The Icelandic passive". Natural Language and Linguistic Theory 3: 441-483.

Zwart, J.-W. 1991. "Clitics in Dutch: evidence for the position of INFL". Groninger Arbeiten zur Germanistischen Linguistik 33: 71-92. 